\title{
Expansion of HIV Preexposure Prophylaxis to 35 PEPFAR-Supported Early Program Adopters, October 2016-September 2018
}

\author{
Gaston Djomand, $\mathrm{MD}^{1}$; Trista Bingham, $\mathrm{PhD}^{1}$; Irene Benech, $\mathrm{MD}^{1}$; Mercy Muthui, MPH${ }^{1}$; Helen Savva, MPH${ }^{1}$; Stella Alamo, MD ${ }^{1}$; \\ Chomnad Manopaiboon, MS ${ }^{1}$; Tisha Wheeler, $\mathrm{MPH}^{2}$; Sasha Mital, $\mathrm{PhD}^{1}$
}

The U.S. President's Emergency Plan for AIDS Relief (PEPFAR), the largest bilateral funder of human immunodeficiency virus (HIV) prevention and control programs worldwide, currently supports implementation of preexposure prophylaxis (PrEP) to reduce HIV incidence among persons at substantial risk for infection, including female sex workers, men who have sex with men (MSM), and transgender women (hereafter referred to as key populations). Recent estimates suggest that $54 \%$ of all global new HIV infections in 2018 occurred among key populations and their sexual partners (1). In 2016, PEPFAR began tracking initiation of PrEP by key populations and other groups at high risk (2). The implementation and scale-up of PrEP programs across 35 PEPFAR-supported country or regional programs* was assessed by determining the number of programs reporting any new PrEP clients during each quarter from October 2016 to September 2018. As of September 2018, only 15 (43\%) PEPFAR-supported country or regional programs had implemented PrEP programs; however, client volume increased by $3,351 \%$ over the assessment period in 15 country or regional programs. Scale-up of PrEP among general population clients $(5,255 \%)$ was nearly three times that of key population clients $(1,880 \%)$. Among key populations, the largest increase $(3,518 \%)$ occurred among MSM. Factors that helped drive the success of these PrEP early adopter programs included initiation of national, regional, and multilateral stakeholder meetings; engagement of ministries of health and community advocates; revision of HIV treatment guidelines to include PrEP; training for HIV service providers; and establishment of drug procurement policies. These best practices can help facilitate PrEP implementation, particularly among key populations, in other country or regional programs to reduce global incidence of HIV infection.

International, national, subnational, nongovernmental, and academic PEPFAR implementing partners reported PrEP data from country or regional programs for eight quarters (i.e., October-December 2016 through July-September 2018).

\footnotetext{
*Angola, Asia Region, Botswana, Burma, Burundi, Cambodia, Cameroon, Caribbean Region, Central America Region, Central Asia Region, Côte d'Ivoire, Democratic Republic of the Congo, Dominican Republic, Eswatini, Ethiopia, Ghana, Haiti, India, Indonesia, Kenya, Lesotho, Malawi, Mozambique, Namibia, Nigeria, Papua New Guinea, Rwanda, South Africa, South Sudan,

Tanzania, Uganda, Ukraine, Vietnam, Zambia, and Zimbabwe.
}

The primary outcome measured was the number of persons (including new enrollees) who received PrEP during the reporting period, disaggregated by key population group (i.e., female sex workers, MSM, and transgender women). To assess implementation and scale-up of PrEP, the number and percentage of the 35 PEPFAR-funded country or regional programs that reported PrEP initiation among key populations or the general population and the number of new PrEP clients in each program were determined. The relative percentage change in PrEP initiation for the general population and that in the key populations over time were also compared.

Country or regional programs with $>150$ new key population clients across multiple quarters totaling $\geq 1,000$ clients were classified as early adopters of PrEP among key populations. The threshold of 150 clients per quarter was determined by a minimum enrollment rate of 50 key population clients per month during a quarter. Using previous analyses of PrEP implementation $(3,4)$, critical factors and scale-up accelerators that facilitate early coverage and rapid growth among PrEP programs were identified. This list of factors was provided to implementing partners in the early adopter programs, who were asked to determine whether these factors were relevant to the growth of their respective programs.

During the analysis period, 35 PEPFAR-supported country or regional programs were assessed. Substantial scale-up of PrEP initiation among 15 of these programs took place, commencing with 888 new clients during October-December 2016 and ending with 30,644 during July-September 2018 (Figure), representing a 3,351\% overall increase among general population and key population clients over the assessment period. Scale-up of PrEP initiation among the general population $(5,255 \%$ increase) was nearly three times that among the key populations $(1,880 \%)$, and the increases in PrEP initiation within the key populations substantially varied among key population groups (Table 1). For example, the largest increase in enrollment of new clients within the key populations occurred among MSM (3,518\%), whereas the increase among transgender women was substantially lower (573\%). The percentage of new key population clients among all new PrEP clients varied over the analysis period (range $=29 \%-56 \%$ ) and was $32 \%$ in the most recent quarter (July-September 2018). 
FIGURE. Preexposure prophylaxis (PrEP) initiation among the general population and key populations* - 35 U.S. President's Emergency Plan for AIDS Relief-funded country or regional programs, October 2016-September 2018

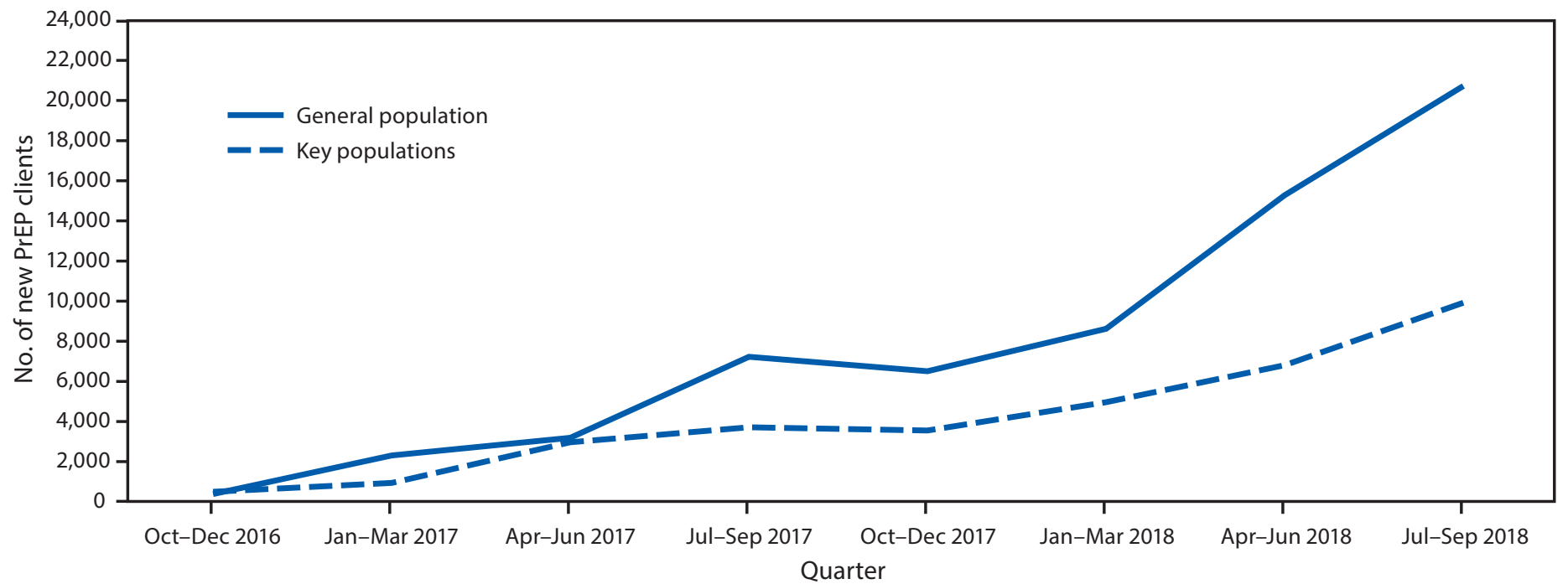

Abbreviation: AIDS = acquired immunodeficiency syndrome.

* Key populations are female sex workers, men who have sex with men, and transgender women.

TABLE 1. Preexposure prophylaxis (PrEP) initiation among general and key populations and percentage change in PrEP initiation in general and key populations - 35 U.S. President's Emergency Plan for AIDS Relief-funded country or regional programs, October 2016-September 2018

\begin{tabular}{|c|c|c|c|c|c|c|c|c|c|}
\hline \multirow[b]{2}{*}{ Characteristic } & \multicolumn{8}{|c|}{ Quarter } & \multirow{2}{*}{$\begin{array}{l}\text { \% Increase } \\
\text { Oct 2016- } \\
\text { Sep } 2018\end{array}$} \\
\hline & $\begin{array}{l}\text { Oct-Dec } \\
2016\end{array}$ & $\begin{array}{l}\text { Jan-Mar } \\
2017\end{array}$ & $\begin{array}{l}\text { Apr-Jun } \\
2017\end{array}$ & $\begin{array}{l}\text { Jul-Sep } \\
2017\end{array}$ & $\begin{array}{l}\text { Oct-Dec } \\
2017\end{array}$ & $\begin{array}{l}\text { Jan-Mar } \\
2018\end{array}$ & $\begin{array}{l}\text { Apr-Jun } \\
2018\end{array}$ & $\begin{array}{l}\text { Jul-Sep } \\
2018\end{array}$ & \\
\hline Total PrEP clients enrolled & 888 & 3,250 & 6,155 & 10,945 & 10,062 & 13,588 & 22,086 & 30,644 & 3,351 \\
\hline General population (\%)* & $387(44)$ & $2,308(71)$ & $3,188(52)$ & $7,228(66)$ & $6,509(65)$ & $8,621(63)$ & $15,277(69)$ & $20,723(68)$ & 5,255 \\
\hline $\begin{array}{l}\text { Key populations }(\%)^{*} \\
\text { Female sex workers }(\%)^{\dagger} \\
\text { Men who have sex with men (\%) }{ }^{\dagger} \\
\text { Transgender women }(\%)^{\dagger}\end{array}$ & $\begin{array}{r}501(56) \\
390(78) \\
89(18) \\
22(4)\end{array}$ & $\begin{array}{r}942(29) \\
709(75) \\
186(20) \\
47(5)\end{array}$ & $\begin{array}{r}2,967(48) \\
1,470(50) \\
1,463(49) \\
34(1)\end{array}$ & $\begin{array}{r}3,717(34) \\
2,125(57) \\
1,495(40) \\
97(3)\end{array}$ & $\begin{array}{r}3,553(35) \\
2,075(58) \\
1,411(40) \\
67(19)\end{array}$ & $\begin{array}{r}4,967(37) \\
3,106(63) \\
1,752(35) \\
109(2)\end{array}$ & $\begin{array}{r}6,809(31) \\
4,098(60) \\
2,615(38) \\
96(1)\end{array}$ & $\begin{array}{r}9,921(32) \\
6,553(66) \\
3,220(32) \\
148(1)\end{array}$ & $\begin{array}{r}1,880 \\
1,580 \\
3,518 \\
573\end{array}$ \\
\hline $\begin{array}{l}\text { No. of country or regional programs } \\
\text { reporting PrEP initiation }\end{array}$ & 5 & 7 & 12 & 11 & 11 & 14 & 15 & 15 & 200 \\
\hline $\begin{array}{l}\text { No. of country or regional programs } \\
\text { reporting PrEP initiation among key } \\
\text { populations }\end{array}$ & 3 & 5 & 8 & 6 & 9 & 11 & 14 & 13 & 333 \\
\hline
\end{tabular}

Abbreviation: AIDS = acquired immunodeficiency syndrome.

* Percentage of all PrEP clients.

† Percentage of all key population clients.

Overall, among 35 PEPFAR-supported country or regional programs, $15^{\dagger}(34 \%)$ have reported providing PrEP services to general population clients, and $13^{\S}$ have reported providing PrEP services to key population clients.

Among all PEPFAR-supported programs, six (Asia Region, Kenya, South Africa, Uganda, Vietnam, and Zimbabwe) were classified as early adopters of PrEP for key populations.

${ }^{\dagger}$ Asia Region, Botswana, Democratic Republic of the Congo, Dominican Republic, Kenya, Lesotho, Namibia, Nigeria, South Africa, Tanzania, Uganda, Ukraine, Vietnam, Zambia, and Zimbabwe. The Asia Region includes China, Laos, and Thailand.

$\$$ Asia Region, Botswana, Dominican Republic, Kenya, Lesotho, Namibia, Nigeria, South Africa, Tanzania, Uganda, Vietnam, Zambia, and Zimbabwe.
Implementing partners in five of these programs (all except Vietnam) identified critical factors for early adoption of PrEP (Table 2), including national and regional stakeholder meetings with strong ongoing engagement and advocacy from ministries of health, community advocates, and multilateral partners such as the World Health Organization and the Joint United Nations Programme on HIV/AIDS (UNAIDS). Five early adopter programs included PrEP services in national treatment and prevention guidelines despite the lack of favorable legal environments to safeguard key populations from violence and discrimination. Early programs also reported standardized, routine HIV service provider training and the ability of their governments to procure PrEP. 
TABLE 2. Critical factors and scale-up accelerators associated with early adoption of expansion of preexposure prophylaxis (PrEP) among key populations in programs supported by the U.S. President's Emergency Plan for AIDS Relief (PEPFAR) - Asia Region, Kenya, South Africa, Uganda, and Zimbabwe, October 2016-September 2018

\begin{tabular}{|c|c|c|c|c|c|}
\hline $\begin{array}{l}\text { Critical factors } \\
\text { and scale-up } \\
\text { accelerators }\end{array}$ & Asia Region & Kenya & South Africa & Uganda & Zimbabwe \\
\hline $\begin{array}{l}\text { National } \\
\text { stakeholder } \\
\text { consultations and } \\
\text { engagement }\end{array}$ & $\begin{array}{l}\text { National consultations on } \\
\text { PrEP held in } 2012\end{array}$ & $\begin{array}{l}\text { National and } \\
\text { multilateral } \\
\text { stakeholders } \\
\text { meetings led by } \mathrm{MOH} \\
\text { in } 2016\end{array}$ & $\begin{array}{l}\text { Extensive stakeholder } \\
\text { consultations with } \\
\text { academics and key } \\
\text { population groups } \\
\text { coordinated by NDoH } \\
\text { in } 2016\end{array}$ & $\begin{array}{l}\text { Multiple consultations } \\
\text { including key } \\
\text { population groups, } \\
\text { MOH, and multilateral } \\
\text { partners in } 2017\end{array}$ & $\begin{array}{l}\text { Wide, multisectoral, } \\
\text { multilateral stakeholder } \\
\text { meetings including key } \\
\text { population groups in } \\
2016\end{array}$ \\
\hline $\begin{array}{l}\text { Favorable legal } \\
\text { environment for } \\
\text { key populations }\end{array}$ & $\begin{array}{l}\text { Not favorable but not } \\
\text { criminalized }\end{array}$ & $\begin{array}{l}\text { Not favorable; strong } \\
\text { MOH advocacy for key } \\
\text { populations and LGBT } \\
\text { persons }\end{array}$ & $\begin{array}{l}\text { Legal protection for } \\
\text { LGBT persons }\end{array}$ & Not favorable & Not favorable \\
\hline $\begin{array}{l}\text { Existing PrEP } \\
\text { treatment } \\
\text { guidelines }\end{array}$ & $\begin{array}{l}\text { National PrEP guidelines } \\
\text { published in } 2018\end{array}$ & $\begin{array}{l}\text { PrEP guidelines } \\
\text { launched in July } 2016\end{array}$ & $\begin{array}{l}\text { National policy on PrEP } \\
\text { developed and } \\
\text { published in } \\
\text { March } 2016\end{array}$ & $\begin{array}{l}\text { PrEP guidelines } \\
\text { developed by } \mathrm{MOH} \text { and } \\
\text { endorsed in } 2017\end{array}$ & $\begin{array}{l}\text { PrEP implementation } \\
\text { plan and guidelines } \\
\text { developed and } \\
\text { launched in } 2018\end{array}$ \\
\hline $\begin{array}{l}\text { HIV service } \\
\text { provider training }\end{array}$ & $\begin{array}{l}\text { Training for health care } \\
\text { workers at hospitals and } \\
\text { health centers in } 13 \\
\text { provinces with high HIV } \\
\text { prevalence }\end{array}$ & $\begin{array}{l}\text { Training, CME, and } \\
\text { clinical mentorship for } \\
\text { HIV service providers }\end{array}$ & $\begin{array}{l}\text { Regular HIV service } \\
\text { provider training for } \\
\text { accredited PrEP centers }\end{array}$ & $\begin{array}{l}\text { Training manual } \\
\text { developed; training } \\
\text { provided at } 70 \text { sites }\end{array}$ & $\begin{array}{l}\text { Oral PrEP training } \\
\text { curriculum developed } \\
\text { and launched }\end{array}$ \\
\hline $\begin{array}{l}\text { Existing drug } \\
\text { procurement } \\
\text { system }\end{array}$ & $\begin{array}{l}\text { National drug } \\
\text { procurement system }\end{array}$ & $\begin{array}{l}\text { National drug } \\
\text { procurement system }\end{array}$ & $\begin{array}{l}\text { PrEP procured by NDoH } \\
\text { with CDC and PEPFAR } \\
\text { funds }\end{array}$ & $\begin{array}{l}\text { National drug } \\
\text { procurement system }\end{array}$ & $\begin{array}{l}\text { Funded through PEPFAR } \\
\text { and pharmaceutical } \\
\text { companies }\end{array}$ \\
\hline $\begin{array}{l}\text { Provision of other } \\
\text { services }\end{array}$ & $\begin{array}{l}\text { PrEP offered as part of } \\
\text { general clinical services }\end{array}$ & $\begin{array}{l}\text { PrEP integrated with } \\
\text { behavioral and clinical } \\
\text { services }\end{array}$ & $\begin{array}{l}\text { Part of HIV combination } \\
\text { prevention for all HIV } \\
\text { service providers }\end{array}$ & $\begin{array}{l}\text { Part of HIV combination } \\
\text { prevention services for } \\
\text { all HIV service providers }\end{array}$ & $\begin{array}{l}\text { Part of HIV combination } \\
\text { prevention services for } \\
\text { all HIV service providers }\end{array}$ \\
\hline $\begin{array}{l}\text { Government's } \\
\text { active ownership }\end{array}$ & $\begin{array}{l}\text { Development of web- } \\
\text { based platform to } \\
\text { monitor PrEP use }\end{array}$ & $\begin{array}{l}\text { Prioritization of key } \\
\text { populations for PrEP } \\
\text { service delivery }\end{array}$ & $\begin{array}{l}\text { NDoH coordination of } \\
\text { PrEP rollout and data } \\
\text { collection }\end{array}$ & $\begin{array}{l}\text { Development of PrEP } \\
\text { implementation tools } \\
\text { and guidelines }\end{array}$ & $\begin{array}{l}\text { National technical } \\
\text { working group to } \\
\text { oversee PrEP } \\
\text { implementation }\end{array}$ \\
\hline $\begin{array}{l}\text { Innovative } \\
\text { demand creation } \\
\text { activities }\end{array}$ & $\begin{array}{l}\text { Promoted through several } \\
\text { social media channels, } \\
\text { websites, and in key } \\
\text { population safe spaces } \\
\text { and meeting places }\end{array}$ & $\begin{array}{l}\text { Promoted through } \\
\text { national campaign, } \\
\text { social media, and at } \\
\text { key population clinics } \\
\text { and meeting places }\end{array}$ & $\begin{array}{l}\text { Done for each key } \\
\text { population with social } \\
\text { media and at drop-in } \\
\text { centers and meeting } \\
\text { places }\end{array}$ & $\begin{array}{l}\text { Promoted through } \\
\text { drop-in centers and the } \\
\text { assistance of peers, peer } \\
\text { educators, and peer } \\
\text { navigators }\end{array}$ & $\begin{array}{l}\text { Done for grassroots key } \\
\text { population } \\
\text { organizations in safe } \\
\text { spaces and key } \\
\text { population clinics }\end{array}$ \\
\hline $\begin{array}{l}\text { Multiple service } \\
\text { delivery models }\end{array}$ & $\begin{array}{l}\text { PrEP provided at eight key } \\
\text { population-led service } \\
\text { centers and in } \\
\text { approximately } 40 \text { public } \\
\text { hospitals and health } \\
\text { centers }\end{array}$ & $\begin{array}{l}\text { PrEP provided at } \\
\text { drop-in centers, } \\
\text { mobile outreach } \\
\text { services }\end{array}$ & $\begin{array}{l}\text { PrEP provided at drop-in } \\
\text { centers and mobile } \\
\text { clinics at key } \\
\text { population meeting } \\
\text { places }\end{array}$ & $\begin{array}{l}\text { PrEP provided by } \\
\text { outreach at drop-in } \\
\text { centers and integrated } \\
\text { into public facilities }\end{array}$ & $\begin{array}{l}\text { PrEP provided at clinics } \\
\text { and by mobile } \\
\text { outreach }\end{array}$ \\
\hline
\end{tabular}

Abbreviations: $\mathrm{CME}=$ continuing medical education; $\mathrm{HIV}=$ human immunodeficiency virus; $\mathrm{LGBT}=$ lesbian, gay, bisexual, and transgender; $\mathrm{MOH}=$ ministry of health; $\mathrm{NDoH}=$ national department of health.

Factors that accelerated PrEP scale-up included active government ownership of the national PrEP program and innovations in PrEP service delivery. Most governments supported PrEP programs by drafting policies and guidelines, developing or adapting PrEP training curricula, accrediting sites, and collecting and reporting data. PrEP marketing innovations, including promoting PrEP outside the typical clinical platform through drop-in centers or key population safe spaces; on social media; at meeting places such as sex clubs and gay bars; and in the community through peer outreach also were critical accelerators (5).

\section{Discussion}

PrEP implementation among key populations has been successful in some PEPFAR-supported programs despite the absence of laws and policies to protect key populations who seek HIV services. That key populations accounted for $29 \%-56 \%$ of all PrEP initiations underscores the relative success of PrEP implementation among these populations, given that they might represent a small proportion of the overall population. PrEP early adopter programs shared several critical characteristics and reported common scale-up accelerators, including cooperation among national governments, PrEP implementers, and community advocates. These factors can 


\section{Summary}

What is already known about this topic?

Preexposure prophylaxis (PrEP) reduces human immunodeficiency virus (HIV) infection incidence.

What is added by this report?

During October 2016-September 2018, in 15 of 35 country or regional programs supported by the U.S. President's Emergency Plan for AIDS Relief, the increase in PrEP coverage among the general population was approximately triple that among female sex workers, men who have sex with men, and transgender women. Critical factors associated with successful PrEP implementation in these populations include stakeholder engagement, existing PrEP delivery guidelines, HIV service provider training, and a drug procurement system.

What are the implications for public health practice?

Sharing best practices could facilitate adoption of PrEP in other country or regional programs and contribute to epidemic control.

provide insights for programs that have not yet introduced or sufficiently scaled PrEP services to reach key populations.

As of October 2018, only 13 of 35 PEPFAR-supported country or regional programs were implementing PrEP for key populations. The findings in this report suggest that global and regional advocacy can help engage community stakeholders and encourage governments to develop national PrEP guidelines in programs that have yet to implement PrEP. For programs currently providing PrEP services, the scale-up accelerators identified in this report can help streamline services to key populations by integrating PrEP into a combination prevention strategy. For example, a successful PrEP program can attract persons seeking to learn their HIV status and subsequently identify HIV-negative persons at substantial risk for HIV, identify previously undiagnosed HIV-positive persons, and link patients with newly diagnosed HIV infection to rapid antiretroviral therapy initiation (G). This simultaneous delivery of PrEP and antiretroviral therapy services could synergize prevention, early identification of HIV-positive persons, and treatment to achieve epidemic control (7).

Because the effectiveness of PrEP depends upon consistent use among persons at continued risk, monitoring adherence to PrEP and retention in the program is important. Since 2019, PEPFAR has required programs to monitor PrEP adherence, retention, coverage, and potential impact (2). Novel PrEP delivery mechanisms (e.g., event-driven PrEP and long-acting PrEP injectable drugs) are being explored as alternatives to daily oral PrEP. One study in Thailand concluded that incorporating PrEP delivery into existing antiretroviral therapy programs could be a cost-effective strategy to prevent HIV infection among MSM (5).
The findings in this report are subject to at least two limitations. First, PrEP retention data were not collected; therefore, the impact of PrEP scale-up on epidemic control is unknown. Recognizing the need to quantify how long persons remain on PrEP, PEPFAR introduced a reporting indicator in October 2018 to track retention. Second, it is possible that, because of stigma, some participants did not disclose their status as members of key populations, leading to underestimation of the proportion of key populations initiating PrEP. To improve the correct classification of key population status among PrEP initiates, PEPFAR continues to support the efforts of country or regional programs to collect key population information that is equally important for clinical management of clients.

PrEP implementation in PEPFAR-supported country or regional programs is gradually increasing among general and key populations. Scale-up of this HIV prevention method in all populations at substantial risk and sharing best practices could contribute to faster HIV epidemic control. Cost-effectiveness and mathematical modeling studies might be useful to help identify subpopulations for PrEP delivery to achieve the greatest HIV prevention impact in resource-limited settings, including other PEPFAR programs.

Corresponding author: Gaston Djomand, gdd7@cdc.gov, 404-639-8929.

${ }^{1}$ Division of Global HIV and TB, Center for Global Health, CDC; ${ }^{2}$ U.S. Agency for International Development, Washington, D.C.

All authors have completed and submitted the International Committee of Medical Journal Editors form for disclosure of potential conflicts of interest. No potential conflicts of interest were disclosed.

\section{References}

1. Joint United Nations Programme on HIV/AIDS. UNAIDS data 2019: Geneva, Switzerland: Joint United Nations Programme on HIV/AIDS; 2018. https:// www.unaids.org/sites/default/files/media_asset/2019-UNAIDS-data_en.pdf

2. US President's Emergency Plan for AIDS Relief. Monitoring, evaluation, and reporting indicator reference guide. Washington, DC: US President's Emergency Plan for AIDS Relief; 2018. https://www.state.gov/ pepfar-fiscal-year-2020-monitoring-evaluation-and-reporting-guidance/

3. Mailman School of Public Health. ICAP pre-exposure prophylaxis (PrEP) package. New York City, New York: Columbia University; 2018. https://icap. columbia.edu/tools_resources/icap-pre-exposure-prophylaxis-prep-package-2

4. Reed JB, Patel RR, Baggaley R. Lessons from a decade of voluntary medical male circumcision implementation and their application to HIV preexposure prophylaxis scale up. Int J STD AIDS 2018;29:1432-43. https:// doi.org/10.1177/0956462418787896

5. Suraratdecha C, Stuart R, Manopaiboon C, et al. Cost and cost-effectiveness analysis of pre-exposure prophylaxis among men who have sex with men in two hospitals in Thailand. J Int AIDS Soc 2018;21(Suppl 5):e25129. https://doi.org/10.1002/jia2.25129

6. World Health Organization. HIV strategic information for impact: cascade data use manual to identify gaps in HIV and health services for program improvement. Geneva, Switzerland: World Health Organization; 2019. https:/apps.who.int/ iris/bitstream/handle/10665/273119/9789241514415-eng.pdf?ua=1

7. Joint United Nations Programme on HIV/AIDS. Fast-track: ending the AIDS epidemic by 2030. Geneva, Switzerland: Joint United Nations Programme on HIV/AIDS; 2018. https://www.unaids.org/sites/default/ files/media_asset/JC2686_WAD2014report_en.pdf 